\title{
Fructobacillus tropaeoli sp. nov., a fructophilic lactic acid bacterium isolated from a flower
}

\author{
Correspondence \\ Akihito Endo \\ pegaman@hotmail.co.jp
}

\author{
Akihito Endo, ${ }^{1}$ Tomohiro Irisawa, ${ }^{2}$ Yuka Futagawa-Endo, ${ }^{1}$ \\ Kenji Sonomoto, ${ }^{3}$ Kikuji Itoh, ${ }^{4}$ Katsumi Takano, ${ }^{2}$ Sanae Okada ${ }^{2}$ \\ and Leon M. T. Dicks ${ }^{1}$
${ }^{1}$ Department of Microbiology, University of Stellenbosch, Stellenbosch 7600, South Africa
${ }^{2}$ Department of Applied Biology and Chemistry, Faculty of Applied Biosciences, Tokyo University of Agriculture, Tokyo 156-8502, Japan
${ }^{3}$ Department of Bioscience and Biotechnology, Faculty of Agriculture, Graduate School, Kyushu University, Fukuoka 812-8582, Japan
${ }^{4}$ Graduate School of Agriculture and Life Sciences, University of Tokyo, Tokyo 113-8657, Japan

At the time of writing, the genus Fructobacillus comprised four species: Fructobacillus fructosus, Fructobacillus durionis, Fructobacillus ficulneus and Fructobacillus pseudoficulneus (Endo \& Okada, 2008). These four species were formerly classified as species of the genus Leuconostoc (Antunes et al., 2002; Chambel et al., 2006; Leisner et al., 2005) but were reclassified by Endo \& Okada (2008) as members of a novel genus, Fructobacillus, based on their phylogenetic positions and their morphological and biochemical characteristics. Species of the genus Fructobacillus typically show a preference for D-fructose over D-glucose as a growth substrate and, as such, are classified as fructophilic lactic acid bacteria (Endo \& Okada, 2008). Two distinct groups of fructophilic lactic acid bacteria have been reported; obligate fructophiles and facultative fructophiles (Endo et al., 2009). The four species of the genus Fructobacillus,

The GenBank/EMBL/DDBJ accession numbers for the $16 \mathrm{~S}$ rRNA and recA gene sequences of strain $\mathrm{F} 214-1^{\top}$ are AB542054 and AB542055, respectively.

Four supplementary figures and one supplementary table are available with the online version of this paper. as well as Lactobacillus kunkeei, are regarded as obligately fructophilic and the novel species Lactobacillus florum is regarded as facultatively fructophilic (Endo et al., 2009, 2010). The two groups differ in their ability to grow on D-glucose without electron acceptors and to produce ethanol from D-glucose (Endo et al., 2009, 2010).

During the course of our studies on fructophilic lactic acid bacteria, one strain, designated F214-1 ${ }^{\mathrm{T}}$, was isolated from a flower in South Africa. The strain showed biochemical characteristics typical of obligately fructophilic lactic acid bacteria and, based on 16S rRNA gene sequence analyses, formed a phylogenetic subcluster with $F$. ficulneus and $F$. pseudoficulneus in the Fructobacillus cluster. Based on DNA-DNA relatedness values, strain $\mathrm{F} 214-1^{\mathrm{T}}$ was genetically distinct from these close relatives. Here, we describe the taxonomic characterization of strain $\mathrm{F} 214-1^{\mathrm{T}}$ and propose that it represents a novel species of the genus Fructobacillus.

Strain F214- ${ }^{\mathrm{T}}$ was isolated from a nasturtium flower (Tropaeolum majus) in Stellenbosch, Western Cape, South Africa, in June 2009. Fresh flowers were collected and 
crushed in a sterile plastic bag. A $1 \mathrm{ml}$ aliquot of FYP broth, composed of $\left(\mathrm{g} \mathrm{l}^{-1}\right)$ D-fructose (10), yeast extract (10), polypeptone (5), sodium acetate (2), Tween 80 (0.5), $\mathrm{MgSO}_{4} \cdot 7 \mathrm{H}_{2} \mathrm{O}(0.2), \mathrm{MnSO}_{4} \cdot 4 \mathrm{H}_{2} \mathrm{O}(0.01), \mathrm{FeSO}_{4} \cdot 7 \mathrm{H}_{2} \mathrm{O}$ (0.01), $\mathrm{NaCl}(0.01)$, cycloheximide (0.05) and sodium azide (0.05; $\mathrm{pH} 6.8)$, was added to the crushed samples and the bags were incubated at $30{ }^{\circ} \mathrm{C}$ for $24 \mathrm{~h}$. After incubation, each sample was inoculated into FYP broth by using a loop and incubated at $30{ }^{\circ} \mathrm{C}$ under aerobic conditions on an orbital shaker (120 r.p.m.) for 2 days. The culture was then streaked onto FYP agar plates containing $\left(1^{-1}\right) 5 \mathrm{~g} \mathrm{CaCO}_{3}$ and $12 \mathrm{~g}$ agar. The plates were incubated at $30{ }^{\circ} \mathrm{C}$ under aerobic conditions until visible colonies were observed. Colonies were selected based on differences in morphology, such as colony size and shape, and the clearance zone formed from hydrolysis of $\mathrm{CaCO}_{3}$ by lactic acid, inoculated into FYP broth and GYP broth and incubated statically for $24 \mathrm{~h}$ at $30{ }^{\circ} \mathrm{C}$. GYP broth differed from FYP broth by containing $10 \mathrm{~g} \mathrm{l}^{-1} \mathrm{D}$-glucose instead of D-fructose.

Strain F214-1 ${ }^{\mathrm{T}}$ grew well in FYP broth but poorly in GYP broth and was, therefore, regarded as a fructophilic lactic acid bacterium. The strain was stored at $-80{ }^{\circ} \mathrm{C}$ in nutrient broth containing $20 \%(\mathrm{v} / \mathrm{v})$ glycerol. Strains $F$. durionis LMG $22556^{\mathrm{T}}$, F. ficulneus JCM $12225^{\mathrm{T}}$, F. fructosus NRIC $1058^{\mathrm{T}}$ and F. pseudoficulneus DSM $14568^{\mathrm{T}}$ were cultured in FYP broth and used as reference strains.

The 16S rRNA gene sequence of strain $\mathrm{F} 214-1^{\mathrm{T}}$ was determined as described previously (Endo \& Okada, 2005). The closest recognized relatives of the isolate were determined by performing database searches and sequences of closely related species were retrieved from DDBJ. Multiple sequence alignments were carried out by using CLUSTAL_X, version 1.18 (Thompson et al., 1997). Distance matrices for the aligned sequences were calculated by using the two-parameter method of Kimura (1980) and phylogenetic trees were reconstructed by using the neighbourjoining, maximum-likelihood and maximum-parsimony methods in PHYLIP version 3.65 software as described previously (Endo \& Okada, 2006). 16S rRNA gene sequences $(\sim 1450 \mathrm{bp})$ of the isolate and related species of lactic acid bacteria were used to reconstruct phylogenetic trees. The highest sequence similarities to strain F $214-1^{\mathrm{T}}$ were 99.2 and $98.0 \%$ to F. pseudoficulneus and F. ficulneus, respectively. In the tree reconstructed using the neighbourjoining method, the strain formed a subcluster with $F$. pseudoficulneus and F. ficulneus within the Fructobacillus phylogenetic cluster (Fig. 1). An identical tree topology was obtained when using the maximum-likelihood and maximum-parsimony methods (see Supplementary Figs S1 and S2, available in IJSEM Online).

As an additional genetic marker, the $\operatorname{rec} A$ gene of strain F214- $1^{\mathrm{T}}$ was sequenced and used for phylogenetic analysis. The $r e c A$ gene encodes a recombinase A protein and using this sequence in phylogenetic analyses gives greater resolution than the 16S rRNA gene sequence when classifying members of the genera Leuconostoc and Fructobacillus
(Ehrmann et al., 2009; Endo \& Okada, 2008). Amplification, purification and partial sequencing of the recA gene were performed as described previously (Endo \& Okada, 2008). Phylogenetic analysis was conducted as described above and a phylogenetic tree was reconstructed by the neighbour-joining method using $\sim 500 \mathrm{bp}$ recA gene sequences of the isolate and related species of lactic acid bacteria. Lactococcus lactis IL1403 was used as an outgroup. In the phylogenetic tree, strain F214- ${ }^{\mathrm{T}}$ formed a subcluster with F. ficulneus within the Fructobacillus cluster (Fig. 2). Sequence similarities based on the recA gene of strain F214-1 ${ }^{\mathrm{T}}$ and related species of the genus Fructobacillus ranged from 83.0 to $85.6 \%$. Other studies have shown that recA gene sequence similarities were $>99 \%$ between different strains of Lactobacillus plantarum but $<87 \%$ between different species of the genus Lactobacillus (Torriani et al., 2001), supporting the assumption that strain $\mathrm{F} 214-1^{\mathrm{T}}$ represents a distinct species and not a separate strain.

DNA-DNA relatedness between strain $\mathrm{F} 214-1^{\mathrm{T}}$ and reference strains $F$. durionis LMG $22556^{\mathrm{T}}, F$. fructosus NRIC $1058^{\mathrm{T}}, F$. ficulneus JCM $12225^{\mathrm{T}}$ and F. pseudoficulneus DSM $15468^{\mathrm{T}}$ and the DNA G $+\mathrm{C}$ content of the isolate were determined as described by Endo \& Okada (2006). Extraction and purification of bacterial DNA were performed according to the methods of Marmur (1961) with modifications (Ezaki et al., 1983). Strain F214-1 ${ }^{\mathrm{T}}$ showed DNA-DNA relatedness values of $11-19 \%$ with the reference strains (Supplementary Table S1) and had a G + C content of $44 \mathrm{~mol} \%$.

Morphological, physiological and biochemical characteristics of strain $\mathrm{F} 214-1^{\mathrm{T}}$ were determined as described previously (Endo et al., 2009). FYP broth was used as basal medium. Acid production from carbohydrates and enzyme activities were determined for strain F214- $1^{\mathrm{T}}$ and the four reference strains using API $50 \mathrm{CH}$ and API ZYM strips (bioMérieux). Detailed characteristics of strain F214- ${ }^{\mathrm{T}}$ and reference strains of the genus Fructobacillus are given in the species description and in Table 1. Of the 49 carbohydrates tested, strain F214- ${ }^{\mathrm{T}}$ only produced acid from D-fructose, D-glucose and Dmannitol and metabolized D-fructose faster than D-glucose. These results and those from enzymic assays were very similar between strain $\mathrm{F} 214-\mathrm{1}^{\mathrm{T}}$ and other members of the genus Fructobacillus (Table 1). These shared physiological and biochemical properties make classification based on these characteristics difficult. On the other hand, sequence analysis of housekeeping genes, such as $r e c A$, can be a powerful tool for classifying species of the genus Fructobacillus.

Growth characteristics of strain F214- $1^{\mathrm{T}}$ were determined as described previously (Endo et al., 2009). Broth containing Dglucose, D-fructose or D-glucose with $1 \%$ pyruvate was used in this study. To determine growth enhancement in the presence of $\mathrm{O}_{2}$, cells of strain $\mathrm{F} 214-1^{\mathrm{T}}$ were grown in broth containing D-glucose under aerobic (120 r.p.m. by orbital shaker) and static conditions. Growth on GYP agar under aerobic and anaerobic (Anaerobic stystem BR0038B; Oxoid) conditions was also determined. Presence of end products from the fermentation of $\mathrm{D}$-glucose was determined as 


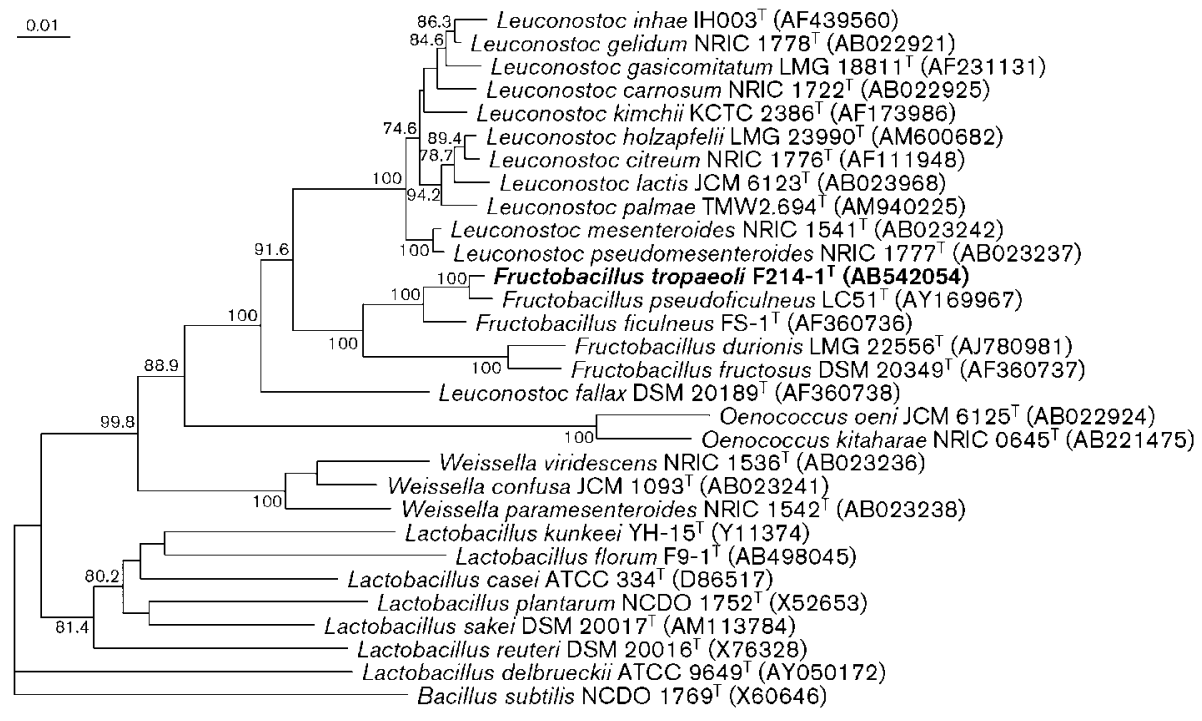

Fig. 1. Phylogenetic relationship of strain $\mathrm{F} 214-1^{\top}$ to related species of lactic acid bacteria based on $16 \mathrm{~S}$ rRNA gene sequences. The tree was reconstructed by using the neighbour-joining method. Bacillus subtilis NCDO $1769^{\top}$ was used as an outgroup. Bootstrap percentages $>70 \%$ are given at branching points. Bar, 0.01 substitutions per nucleotide position.

described previously (Endo et al., 2009). Strain F214-1 ${ }^{\mathrm{T}}$ grew very poorly on $\mathrm{D}$-glucose but grew well on $\mathrm{D}$-fructose (Supplementary Fig. S3). However, the novel strain grew very well on D-glucose in the presence of $1 \%$ pyruvate and under aerobic (shaking) conditions (Supplementary Fig. S3), which suggests that it requires external electron acceptor(s) for the metabolism of D-glucose. Culturing under aerobic conditions enhanced the growth of the strain on agar medium (Supplementary Fig. S4). Colonies grown on GYP agar for 2 days under aerobic conditions were $\sim 1-2 \mathrm{~mm}$ in diameter but under anaerobic conditions were only $\sim 0.1-0.2 \mathrm{~mm}$ in diameter (Anaerobic system BR0038B; Oxoid). Strain F214$1^{\mathrm{T}}$ produced gas from D-glucose but produced almost equimolar amounts of lactic acid and acetic acid and very little ethanol (molar ratio of $1: 1: 0.005$, respectively). These characteristics were unique to strain $\mathrm{F} 214-1^{\mathrm{T}}$ when compared with the characteristics of species of the obligately heterofermentative group of lactic acid bacteria but correlated well with those of the obligately fructophilic group of lactic acid bacteria, which includes species of the genus Fructobacillus (Endo \& Okada, 2008; Endo et al., 2009).

Based on these data, strain F214- $1^{\mathrm{T}}$ represents a novel species of obligately fructophilic lactic acid bacteria in the genus Fructobacillus, for which the name Fructobacillus tropaeoli sp. nov. is proposed. The type strain is F214-1 ${ }^{\mathrm{T}}$ $\left(=\right.$ JCM $16675^{\mathrm{T}}=$ DSM $\left.23246^{\mathrm{T}}\right)$.

\section{Description of Fructobacillus tropaeoli sp. nov.}

Fructobacillus tropaeoli (tro.pae.o'li. N.L. n. Tropaeolum a botanical generic name; N.L. gen. n. tropaeoli of Tropaeolum, isolated from Tropaeolum majus).

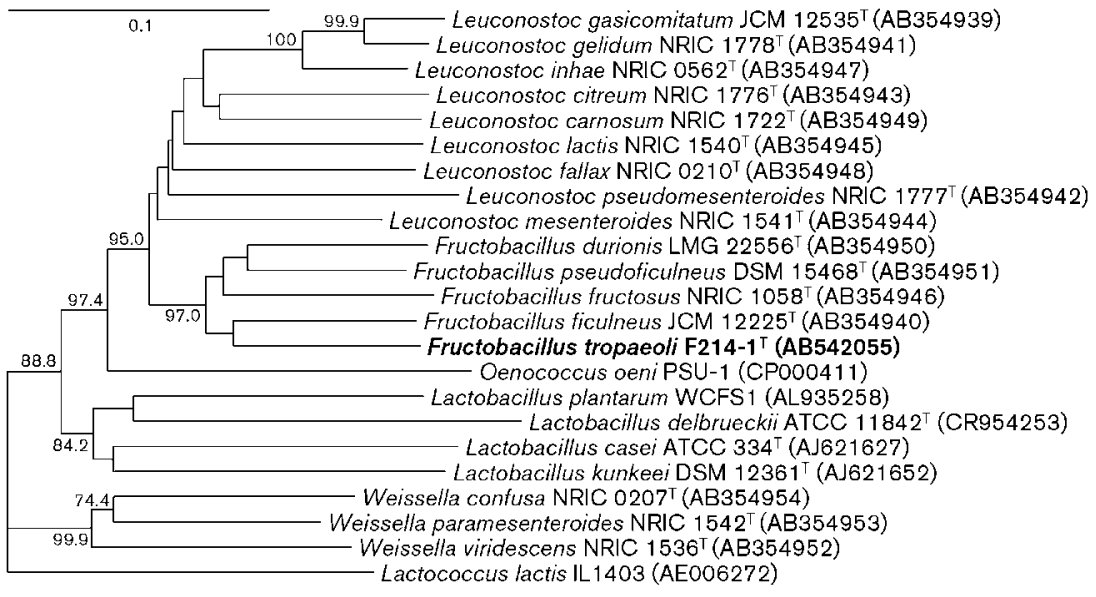

Fig. 2. Phylogenetic relationship of strain $\mathrm{F} 214-1^{\top}$ to related species of lactic acid bacteria based on recA gene sequences. The tree was reconstructed by using the neighbour-joining method. Lactococcus lactis IL1403 was used as an outgroup. Bootstrap percentages $>70 \%$ are given at branching points. Bar, 0.1 substitutions per nucleotide position. 
Table 1. Differential characteristics of strain $F 214-1^{\top}$ and related members of the genus Fructobacillus

Strains: 1, strain F214-1 ${ }^{\mathrm{T}} ; 2$, F. durionis LMG $22556^{\mathrm{T}}$; 3, F. ficulneus JCM $12225^{\mathrm{T}}$; 4, F. fructosus NRIC $1058^{\mathrm{T}}$; 5, F. pseudoficulneus DSM $15468^{\mathrm{T}}$. All results from this study. All strains were positive for acid phosphatase and phosphoamidase activities and negative for caprylate esterase (C8), leucine, valine and cysteine aminopeptidase, $\beta$-galactosidase, $\beta$-glucuronidase, $\alpha$ - and $\beta$-glucosidase, $\beta$ glucosaminidase, $\alpha$-mannosidase and $\alpha$-fucosidase activities. + , Positive; - , negative; $\mathrm{w}$, weakly positive. For acid production, the number of days required for fermentation are indicated in parentheses.

\begin{tabular}{|c|c|c|c|c|c|}
\hline Characteristic & 1 & 2 & 3 & 4 & 5 \\
\hline \multicolumn{6}{|l|}{ Acid production from: } \\
\hline D-Fructose & $+(1)$ & $+(1)$ & $+(1)$ & $+(1)$ & $+(1)$ \\
\hline D-Glucose & $+(2)$ & $+(3)$ & $+(4)$ & $+(4)$ & $+(3)$ \\
\hline D-Mannitol & $+(5)$ & $+(5)$ & $+(6)$ & $+(6)$ & $+(6)$ \\
\hline Sucrose & - & $+(3)$ & $\mathrm{w}$ & - & - \\
\hline Turanose & - & $+(4)$ & $\mathrm{W}$ & - & - \\
\hline D-Ribose & - & $\mathrm{W}$ & - & - & - \\
\hline Gluconate & - & $\mathrm{W}$ & $\mathrm{w}$ & - & - \\
\hline $\begin{array}{l}\text { Methyl } \alpha \text {-D- } \\
\text { glucopyranoside }\end{array}$ & - & $+(6)$ & $\mathrm{w}$ & - & - \\
\hline Maltose & - & $+(7)$ & $\mathrm{w}$ & - & - \\
\hline Trehalose & - & $+(6)$ & $+(5)$ & - & - \\
\hline \multicolumn{6}{|l|}{$\begin{array}{l}\text { Enzyme activities } \\
\text { (API ZYM) }\end{array}$} \\
\hline Alkaline phosphatase & + & $\mathrm{w}$ & + & $\mathrm{w}$ & $\mathrm{w}$ \\
\hline Butyrate esterase (C4) & - & - & $\mathrm{W}$ & - & $\mathrm{W}$ \\
\hline Myristate lipase (C14) & - & - & - & - & $\mathrm{w}$ \\
\hline Trypsin & - & $\mathrm{w}$ & $\mathrm{W}$ & - & $\mathrm{w}$ \\
\hline Chymotrypsin & + & + & + & $\mathrm{W}$ & $\mathrm{W}$ \\
\hline$\alpha$-Galactosidase & - & W & $\mathrm{W}$ & - & $\mathrm{W}$ \\
\hline
\end{tabular}

Cells are Gram-reaction-positive, non-motile rods, $0.8 \times$ 1.5-6 $\mu \mathrm{m}$. Cells occur singly, in pairs or in chains. Facultatively anaerobic and catalase-negative. Obligately fructophilic lactic acid bacteria. Growth on D-glucose is enhanced with external electron acceptors, such as pyruvate and oxygen. Growth on D-glucose is suppressed under anaerobic conditions. After incubation for 2 days on GYP agar, colonies are white, smooth and $\sim 1-2 \mathrm{~mm}$ in diameter under aerobic conditions but only $\sim 0.1-0.2 \mathrm{~mm}$ in diameter under anaerobic conditions. Heterofermentative and produces lactic and acetic acid from D-glucose at a ratio of $1: 1$ along with very small amounts of ethanol. Gas is produced from D-glucose, D- and L-lactate are produced at a ratio of $9: 1$ and mannitol is produced from $D$-fructose. Nitrate is not reduced. Acid is only produced from D-fructose, D-glucose and mannitol. D-Fructose is fermented faster than D-glucose. Acid is not produced from D- or L-arabinose, D- or L-arabitol, $\mathrm{N}$-acetylglucosamine, maltose, ribose, adonitol, amygdalin, arbutin, cellobiose, dulcitol, aesculin, erythritol, D- or L-fucose, $\beta$-gentiobiose, 2- or 5-ketogluconate, potassium gluconate, methyl $\alpha$-D-glucoside, glycerol, glycogen, myo-inositol, inulin, D-lyxose, D-mannose, methyl $\alpha$-D-mannoside, melezitose, raffinose, rhamnose, sucrose, salicin, starch, sorbitol, L-sorbose, D-tagatose, trehalose, turanose, xylitol, L-xylose, methyl $\beta$-xyloside, D-galactose, lactose, melibiose or D-xylose. Dextran is not produced from sucrose. Grows at $15{ }^{\circ} \mathrm{C}$ and weakly at $10{ }^{\circ} \mathrm{C}$ but not at $45{ }^{\circ} \mathrm{C}$. Grows at $\mathrm{pH} 4-8$ and in the presence of $2.5 \%(\mathrm{w} / \mathrm{v}) \mathrm{NaCl}$. Does not grow in the presence of $300 \mathrm{~g} \mathrm{l}^{-1} \mathrm{D}$-fructose. Cells do not contain meso-diaminopimelic acid in their peptidoglycan.

The type strain, F214- $1^{\mathrm{T}}\left(=\mathrm{JCM} 16675^{\mathrm{T}}=\mathrm{DSM} 23246^{\mathrm{T}}\right)$, was isolated from a nasturtium flower collected at Stellenbosch, Western Cape, South Africa, in 2009. The DNA G $+C$ content of the type strain is $44 \mathrm{~mol} \%$.

\section{Acknowledgements}

We are grateful to J. P. Euzéby for advice on the naming of the novel species. A.E. received a post-doctoral scholarship from the Claude Leon Foundation, Cape Town, South Africa. This work was partially supported by the South Africa/Japan Science and Technology Agency Cooperation Programme.

\section{References}

Antunes, A., Rainey, F. A., Nobre, M. F., Schumann, P., Ferreira, A. M., Ramos, A., Santos, H. \& da, C. M. (2002). Leuconostoc ficulneum sp. nov., a novel lactic acid bacterium isolated from a ripe fig, and reclassification of Lactobacillus fructosus as Leuconostoc fructosum comb. nov. Int J Syst Evol Microbiol 52, 647-655.

Chambel, L., Chelo, I. M., Zé-Zé, L., Pedro, L. G., Santos, M. A. \& Tenreiro, R. (2006). Leuconostoc pseudoficulneum sp. nov., isolated from a ripe fig. Int J Syst Evol Microbiol 56, 1375-1381.

Ehrmann, M. A., Freiding, S. \& Vogel, R. F. (2009). Leuconostoc palmae sp. nov., a novel lactic acid bacterium isolated from palm wine. Int $J$ Syst Evol Microbiol 59, 943-947.

Endo, A. \& Okada, S. (2005). Lactobacillus satsumensis sp. nov., isolated from mashes of shochu, a traditional Japanese distilled spirit made from fermented rice and other starchy materials. Int J Syst Evol Microbiol 55, 83-85.

Endo, A. \& Okada, S. (2006). Oenococcus kitaharae sp. nov., a nonacidophilic and non-malolactic-fermenting oenococcus isolated from a composting distilled shochu residue. Int J Syst Evol Microbiol 56, 2345-2348.

Endo, A. \& Okada, S. (2008). Reclassification of the genus Leuconostoc and proposals of Fructobacillus fructosus gen. nov., comb. nov., Fructobacillus durionis comb. nov., Fructobacillus ficulneus comb. nov. and Fructobacillus pseudoficulneus comb. nov. Int J Syst Evol Microbiol 58, 2195-2205.

Endo, A., Futagawa-Endo, Y. \& Dicks, L. M. T. (2009). Isolation and characterization of fructophilic lactic acid bacteria from fructose-rich niches. Syst Appl Microbiol 32, 593-600.

Endo, A., Futagawa-Endo, Y., Sakamoto, M., Kitahara, M. \& Dicks, L. M. (2010). Lactobacillus florum sp. nov., a fructophilic species isolated from flowers. Int J Syst Evol Microbiol 60, 2478-2482.

Ezaki, T., Yamamoto, N., Ninomiya, K., Suzuki, S. \& Yabuuchi, E. (1983). Transfer of Peptococcus indolicus, Peptococcus asaccharolyticus, Peptococcus prevotii, and Peptococcus magnus to the genus Peptostreptococcus and proposal of Peptostreptococcus tetradius sp. nov. Int J Syst Bacteriol 33, 683-698. 
Kimura, M. (1980). A simple method for estimating evolutionary rates of base substitutions through comparative studies of nucleotide sequences. J Mol Evol 16, 111-120.

Leisner, J. J., Vancanneyt, M., Van der Meulen, R., Lefebvre, K., Engelbeen, K., Hoste, B., Laursen, B. G., Bay, L., Rusul, G. \& other authors (2005). Leuconostoc durionis sp. nov., a heterofermenter with no detectable gas production from glucose. Int J Syst Evol Microbiol 55, 1267-1270.

Marmur, J. (1961). A procedure for the isolation of deoxyribonucleic acid from microorganisms. J Mol Biol 3, 208-218.
Thompson, J. D., Gibson, T. J., Plewniak, F., Jeanmougin, F. \& Higgins, D. G. (1997). The CLUSTAL_X windows interface: flexible strategies for multiple sequence alignment aided by quality analysis tools. Nucleic Acids Res 25, 4876-4882.

Torriani, S., Felis, G. E. \& Dellaglio, F. (2001). Differentiation of Lactobacillus plantarum, L. pentosus, and L. paraplantarum by $\operatorname{rec} A$ gene sequence analysis and multiplex PCR assay with recA gene-derived primers. Appl Environ Microbiol 67, 34503454 . 